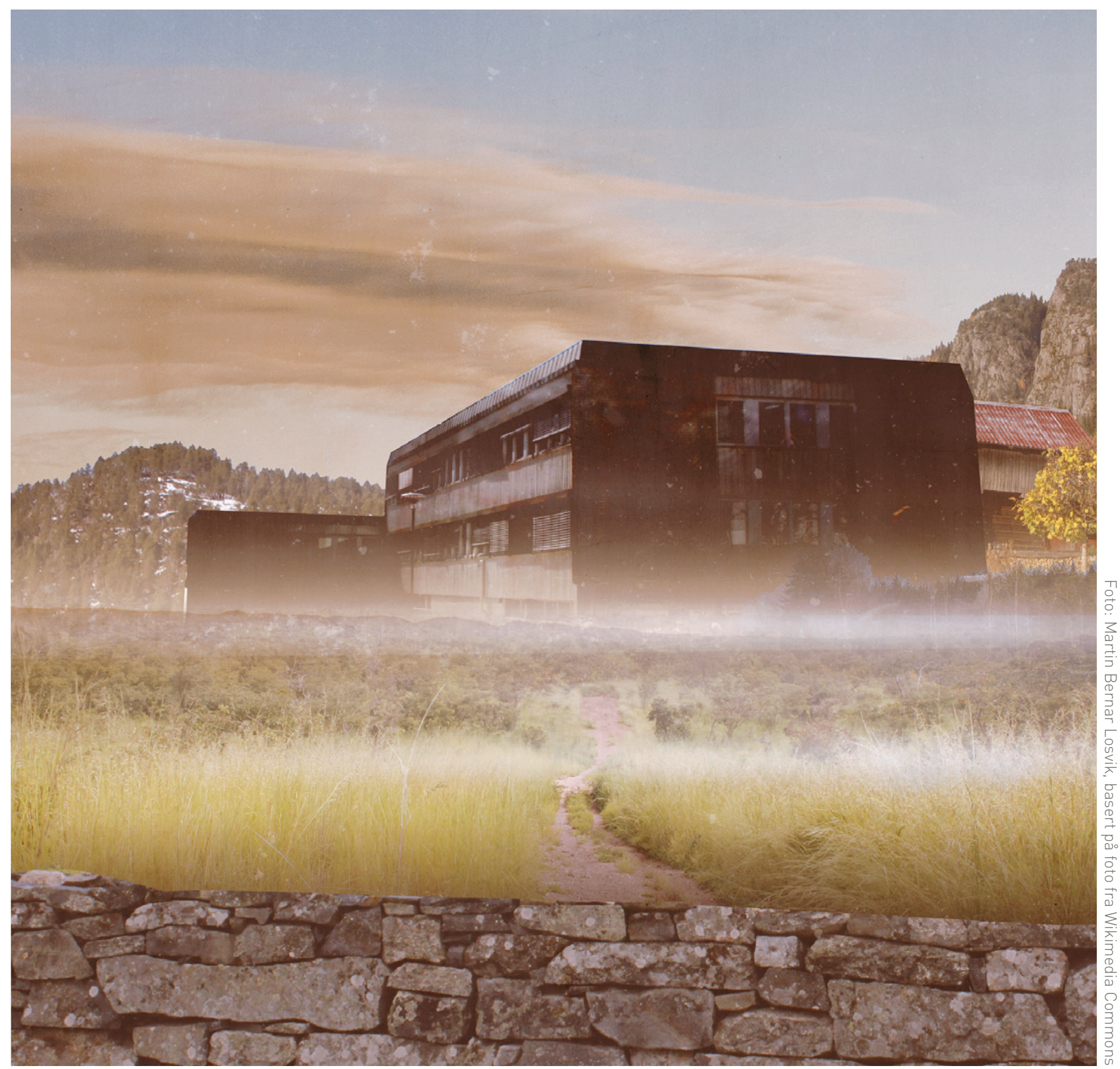

\title{
Nissedal legekontor
}

(i)

Legekontoret er lokalisert i kommunehuset i Treungen i Nissedal kommune i Telemark. Kommunen har totalt 1439 innbyggere og to fastleger - begge plassert i kommunehuset, der det også finnes helsestasjon, fysioterapeut og psykisk helsetjeneste. 